Tropical Agricultural Pesearch \& Extension 22 (3 \& 4): 2019

\title{
SPECIES RICHNESS OF INSECTIVORES BATS AND PHOTOTAXIS INSECTS IN SELECTED TEA PLANTATIONS: POTENTIAL OF BIO- CONTROL OF INSECTS BY BAT PREDATION
}

\author{
Kusuminda $\mathrm{TGT}^{1}$, Amani Mannakkara ${ }^{1 *}$ and Yapa $\mathrm{WB}^{2}$ \\ ${ }^{1}$ Department of Agriculture Biology, Faculty of Agriculture, University of Ruhuna, Kamburupitiya \\ 81100, Sri Lanka. \\ ${ }^{2}$ Department of Zoology and Environment Sciences, Faculty of Science, University of Colombo, Sri \\ Lanka
}

AbSTRaCT

Tea is a prominent plantation crop in Sri Lanka with a significant role in export for generations. Insect pests significantly interfere with the productivity of the tea sector and economically feasible and ecologically acceptable pest management is the primary concern in novel pest management programme. Insectivorous bats served as a predator of nocturnal insects and there is a potential to use as a biocontrol agent of crop pest management. But there is no available literature on bat predation services in tea plantations in Sri Lanka. The present investigation was carried out to study the nocturnal insects and insectivorous bats in selected tea plantations to exploit bats as a potential biocontrol agent in the tea pest management programme. Light traps were used to capture nocturnal insects and mist nets were used to capture bats. According to our result, the abundance of insects in tea ecosystems is typically high according to Shannon's diversity indices throughout the year. Our results revealed that the twelve species of bats representing eight insectivorous bats in five different families foraging in tea plantations. Although we were unable to show the bat predation through this study, it remains to be seen the potential to integrate the insectivorous bats as a predator of the tea insect pests management programme.

Keywords: Insect community, Insectivores bats, Light traps, Tea ecosystem, Tea pest management

\section{INTRODUCTION}

Sri Lanka is the world's leading tea exporter for generations as "Ceylon Tea". In 1867, James Taylor started the first tea plantation [Camellia sinensis (L) OKuntze] in the Loolecondera estate in Kandy in 1867, at present; Sri Lanka has an area of nearly 203,000 ha (Central Bank 2017). With the rapid growth of tea plantation in the country, it is realized the necessity of best practices to cultivate tea. Since an intensive monoculture growing environment, tea plantations are amenable to a large number of pests and diseases. A wide range of arthropods approximately 1031 species have been recorded in tea lands globally causing 11-55\% yield losses (Hazarika et al. 2009). In Sri Lanka, 46 species of insects have been recorded causing varying degrees of damage to tea shrubs (Vitharana 2003). Some key pests of tea such as termites and shot hole borer lead to capital losses due to the death of the

\footnotetext{
*Corresponding author: amani@agbio.ruh.ac.lk
}

plant by a severe infestation. The use of synthetic pesticides to defend against insect pests leads to the rapid conversion of innocuous insects to pests by decreasing natural enemies, development of pest resistance, pesticide residues in made tea.

Made tea is the backbone of the foreign exchange for Sri Lanka and sustainable global competitiveness is dependent on the quality of made tea. As demand for pesticide residues free products in the international market concerns, it is a challenge to minimize pesticides residues in made tea.

Maximum utilization of the biocontrol agents to integrated pest management (IPM) programme is the best option to minimize synthetic pesticide usage in tea plantations. Insectivores bats could be effectively used in the IPM of tea, little or no works were carried out to incorporate insectivores bat into the tea 
IPM programme in Sri Lanka. As insectivores bats are generalist predators of nocturnal insects and other arthropods and their activity and abundance are intensely interrelated with arthropod abundance (Wickramasinghe et al. 2003, 2004). Knowledge of the ecology of bats and availability of food resources in particular ecosystems are crucial to take assessment bats in integrated pest management programmes. Concerning all these facts, this study was intended to provide the abundance of nocturnal insects associated with tea plantations as a food of insectivorous bats and abundance of insectivores bat species in tea plantations and adjacent forests.

\section{MATERIALS AND METHODS}

The fieldwork was performed from January 2017 to December 2017, at Six tea estates corresponding to major six tea-growing regions in Sri Lanka (Table 1 and Figure1).

Light traps were made with a $20 \mathrm{~W}$ mercury vapour fluorescent tube $(30 \mathrm{~cm})$ with four crossed intercepts and a bucket filled with soap water to collect fallen insects. Traps were operated with $12 \mathrm{~V}$ car batteries with a $1000 \mathrm{~W}$ power inverter. Three light traps were set on one sample site and samples were collected from three different heights $(2,4$ and $6 \mathrm{~m})$ from each sample. Light traps were set up at the three vertical levels on the aluminum pole. Traps were operated overnight from 18:00 $\mathrm{hr}$ to the following morning 06:00 $\mathrm{hr}$ and trapped insects were collectedthe following day morning. Collected samples were temporally preserved in $70 \%$ alcohol. Alcohol preserved entomological samples were subjected to further examination at the laboratory and the total number of insects, their order and species levels, were estimated. Collected insect samples were preserved and stored by insect orders in the Entomology laboratory at the Faculty of Agriculture, University of Ruhuna for future references.

At the same time, insectivores bats were captured using three $2.5 \times 12 \mathrm{~m}$ mist nets (mesh size $38 \mathrm{~mm}$ ) fixed on vertical to reached a $7.5 \times 12 \mathrm{~m}$ capture area. Light tarps and mist nets were located on the same shelterbelt. Trapped bats were immediately subjected to morphometric characterization and released to the same site. Batswere identified using regional bat keys and field guides(Phillips, 1980).

Light traps were made with a $20 \mathrm{~W}$ mercury vapour fluorescent tube $(30 \mathrm{~cm})$ with four crossed intercepts and a bucket filled with soap water to collect fallen insects. Traps were operated with $12 \mathrm{~V}$ car batteries with a $1000 \mathrm{~W}$ power inverter. Three light traps were set on one sample site and samples were collected from three different heights $(2,4$ and $6 \mathrm{~m})$ from each sample. Light traps were set up at the three vertical levels on the aluminum pole. Traps were operated overnight from 18:00 hr to the following morning 06:00 $\mathrm{hr}$ and trapped insects were collectedthe following day morning. Collected samples were temporally preserved in $70 \%$ alcohol. Alcohol preserved entomological sam-

Table 1: Geographical locations of the selected tea states for the study

\begin{tabular}{|c|c|c|c|}
\hline $\begin{array}{l}\text { Station } \\
\text { No. }\end{array}$ & Sampling site & Geographical location & Climatic Zone \\
\hline Station 1 & Yatideriya & $07^{0} 07^{\prime} 40.6^{\prime \prime} \mathrm{N} \& 080^{0} 22^{\prime}$ 05.9' $\mathrm{E}$ & Mid country wet zone (WM2) \\
\hline Station 2 & Maskeliya & $06^{0} 52^{\prime} 17.7^{\prime \prime} \mathrm{N} \& 080^{0} 31^{\prime} 53.7^{\prime \prime} \mathrm{E}$ & Upcountry wet zone (WU2) \\
\hline Station 3 & Radella & $06^{0} 55^{\prime} 47.4^{\prime \prime} \mathrm{N} \& 080^{0} 43^{\prime} 37.5^{\prime \prime} \mathrm{E}$ & Upcountry wet zone (WU3) \\
\hline Station 4 & Udupussellawa & $06^{0} 58^{\prime} 08.1^{\prime \prime} \mathrm{N} \& 080^{0} 54^{\prime} 05.1$ ' $\mathrm{E}$ & $\begin{array}{l}\text { Upcountry intermediate zone } \\
\text { (IU2) }\end{array}$ \\
\hline Station 5 & Idulgashenna & $06^{0} 46^{\prime} 36.4^{\prime \prime} \mathrm{N} \& 080^{0} 53^{\prime} 26.1^{\prime \prime} \mathrm{E}$ & $\begin{array}{l}\text { Upcountry intermediate zone } \\
\text { (IU3) }\end{array}$ \\
\hline Station 6 & Thawalama & $06^{0} 22^{\prime} 10.5^{\prime \prime} \mathrm{N} \& 080^{0} 199^{\prime} 27.9{ }^{\prime \prime} \mathrm{E}$ & Low country wet zone (WL1) \\
\hline
\end{tabular}


ples were subjected to further examination at the laboratory and the total number of insects, their order and species levels, were estimated. Collected insect samples were preserved and stored by insect orders in the Entomology laboratory at the Faculty of Agriculture, University of Ruhuna for future references.

All light trapped insects including common and rare ones were investigated for different taxonomic groups and used in statistical analysis for total abundance. All summarizing statistics were produced using Excel. All community analyses were performed with the Statistical Analysis System (SAS 9.1). Data were subjected to analysis of variance to determine whether differences existed among treatment means. Data were considered to be significantly different within the treatments if the F- value obtained was higher than the critical Fvalue at a probability level of 0.01 . When significant differences among treatment means were found, means were tested by Duncan's Multiple Range Test (DMRT) with significance at $P \leq 0.05$. Shannon's diversity indices (H) were calculated to compare insect diversity and richness (Shannon 1948) because it would be more appropriate to reflect both rare and abundant species in the samples (Morris et al. 2014). Finally, light attracted insect communities in the tea ecosystem were discussed from the standpoint of insect abundance and diversity as food resources for insectivores bats.

\section{RESULTS AND DISCUSSION}

The light attracted insect abundance showed significant differences among locations across

Table 2: Result of ANOVA on the abundance of insects collected by light traps during four sampling periods from January to December 2017

\begin{tabular}{llllll}
\hline Source & Ss & df & MS & F & P \\
\hline Location & 4907051.370 & 5 & 981410.274 & 16.20 & $<.0001$ \\
Time & 1566842.222 & 3 & 522280.741 & 8.62 & $<.0001$ \\
Height & 71602.287 & 2 & 35801.144 & 0.59 & 0.5547
\end{tabular}

Table 3: Total abundance of nocturnal insects captured from each experimental site from January to December 2017

\begin{tabular}{|c|c|c|c|c|c|c|c|}
\hline \multicolumn{2}{|c|}{ Station } & 1 & 2 & 3 & 4 & 5 & 6 \\
\hline Time & Height (m) & \multicolumn{6}{|c|}{ Total abundance } \\
\hline January & 2 & $470^{b}$ & $859^{\mathrm{a}}$ & $442.3^{b}$ & $480^{\mathrm{b}}$ & $890^{\mathrm{a}}$ & $1045^{\mathrm{a}}$ \\
\hline \multirow[t]{2}{*}{2017} & 4 & $661^{b c}$ & $958.7^{\mathrm{a}, \mathrm{b}}$ & $524^{\mathrm{c}}$ & $426.3^{c}$ & $1186^{\mathrm{a}}$ & $1135.7^{\mathrm{a}}$ \\
\hline & 6 & $722.2^{\mathrm{b}}$ & $1027.7^{\mathrm{a}, \mathrm{b}}$ & $672.7^{\mathrm{b}}$ & $647^{\mathrm{b}}$ & $1376.3^{\mathrm{a}}$ & $1196^{\mathrm{a}}$ \\
\hline July & 2 & $678^{\mathrm{a}, \mathrm{b}}$ & $598.33^{\mathrm{b}}$ & $764^{\mathrm{a}, \mathrm{b}}$ & $845^{\mathrm{a}}$ & $684.33^{\mathrm{a}, \mathrm{b}}$ & $596.33^{b}$ \\
\hline \multirow[t]{2}{*}{2017} & 4 & $894^{\mathrm{b}}$ & $787^{\mathrm{b}}$ & $840^{\mathrm{b}}$ & $942.7^{\mathrm{b}}$ & $877.7^{\mathrm{b}}$ & $1274.7^{\mathrm{a}}$ \\
\hline & 6 & $939.7^{\mathrm{b}}$ & $1099.3^{\mathrm{a}, \mathrm{b}}$ & $1033.3^{\mathrm{a}, \mathrm{b}}$ & $1342.7^{\mathrm{a}, \mathrm{b}}$ & $1343.7^{\mathrm{a}, \mathrm{b}}$ & $1808.3^{\mathrm{a}}$ \\
\hline October & 2 & $458.67^{\mathrm{b}}$ & $520.67^{\mathrm{a}, \mathrm{b}}$ & $595^{\mathrm{a}, \mathrm{b}}$ & $681.67^{\mathrm{a}}$ & $481^{\mathrm{b}}$ & $469^{b}$ \\
\hline \multirow[t]{2}{*}{2017} & 4 & $680.33^{b c}$ & $532.33^{c}$ & $704^{b, c}$ & $761^{b}$ & $615.67^{\mathrm{b}, \mathrm{c}}$ & $1109^{\mathrm{a}}$ \\
\hline & 6 & $773.3^{\mathrm{b}}$ & $797.7^{\mathrm{b}}$ & $735.7^{\mathrm{b}}$ & $878.3^{\mathrm{b}}$ & $1020^{\mathrm{a}, \mathrm{b}}$ & $1391.7^{\mathrm{a}}$ \\
\hline December & 2 & $617.3^{\mathrm{ab}}$ & $870.7 \mathrm{a}$ & $479.7 \mathrm{~b}$ & $461.7 b$ & $774.3 \mathrm{a}, \mathrm{b}$ & $766.7^{\mathrm{a}, \mathrm{b}}$ \\
\hline \multirow[t]{2}{*}{2017} & 4 & $719.7^{\mathrm{bc}}$ & $968.3^{\mathrm{a}, \mathrm{b}}$ & $593^{\mathrm{c}}$ & $653.3^{c}$ & $964.7^{\mathrm{a}, \mathrm{b}}$ & $1135^{\mathrm{a}}$ \\
\hline & 6 & $749.7^{\mathrm{bc}}$ & $903.3^{\mathrm{a}, \mathrm{b}, \mathrm{c}}$ & $647.7^{\mathrm{b}, \mathrm{c}}$ & $516^{\mathrm{c}}$ & $1306^{\mathrm{a}}$ & $1064^{\mathrm{a}, \mathrm{b}}$ \\
\hline
\end{tabular}

Data are expressed as means \pm SD $(n=3)$. Values within a given row is not followed by the same superscript letter are significantly different at $P \leq 0.05$ as determined by Duncan's Multiple Range Test. 
sampling dates (Table 2). Compared to other stations, significantly high numbers of insects were captured in station 6 throughout the year (Table 03). It is a small-scale tea land in Thawalama which is located in the low country wet zone (WL1). Most of the tea owners in this area are small-scale growers having less than four hectares. Thawalama is an agricultural village with diversified crops including paddy cultivation. Thawalama is located 15.5 $\mathrm{km}$ away from Kanneliya Forest Reserve which is regarded as one of the most biologically diverse areas in the country. Station 5 is a large scale organic tea plantation in Idalgashinna of Badulla District at Uva province located in the upcountry intermediate zone (IU3). Other than one out of 12 samplings, insect abundance in station 5 was not significantly different from that of station 6. (Table 3).

According to the results, the total number of insects captured from stations $1,2.3$ and 4 were not significantly different in most of the sampling occasions (Table 3). However, a considerable amount of insects were caught from all stations throughout the year and the abundance of insects in all tea land is reasonably high since 426.3 to 1808.3 individual insects were collected at each sampling occasion of selected six tea estates (Table 3).

According to the available literature, insects from 32 orders were recorded on the island (Wijesekara \& Wijesinghe 2003), but in this study insects from 16 orders were captured from all locations by light traps. Insects belong to the order Coleoptera, Lepidoptera, Hemiptera, and Isoptera which contain major insect pest of teas were caught in high numbers compared to the other insect orders (Fig 2 \& 3). Shannon's diversity indices $(\mathrm{H})$ vary from 1.2 to 1.9 in all sites accounts for both richness and evenness of the insects up to order levels (Table 04). According to Magurran (1988), ' $\mathrm{H}$ ' value range between 1 to 3.5 and rarely go beyond 4.5 in natural forest. According to the " $\mathrm{H}$ " value, we can suggest that the tea plantations in Sri Lanka covering all tea growing areas showed high insect diversity and richness.

A wide range of insect species depends on tea plants for food or shelter or both. The Shothole borer; (Xyleborus fornicates Eichh.) and live wood termites are recorded as primary tea pests. The Shot-hole borer is occurring in tea plantations up to $1,300 \mathrm{~m}$ elevation and the problem is mainly in the elevation range from $600-900 \mathrm{~m}$ (Vitarana 2003) causing up to $91 \%$ to $100 \%$ infestation in the mid-country wet and dry zones (Walgama and Pallemulla 2005). Two termite species; Glyptotermes dilatatus Bugnion \& Popoff and Neotermes greeni Desneuxa are the most prevalent termite species in low grown tea and Postectrotermes militaris Desneux occurs mostly at the elevation between 1050-1200 m elevations particularly in Maskeliya district. Among the defoliators, Tea tortrix; Homona coffearia Nietner (Lepidoptera: Tortricidae) is reported as dry weather, the seasonal pest of Uva, Mid country and upcountry teas causing over $50 \%$ yield reduction in Sri Lanka (Cranham 1966). Other than the tea tortrix, the considerable number of defoliating caterpillars reported on tea plantations causing economic damage under certain agro-climatic conditions and /or can be promoted up to pest status by human's activities that course changes in the ecosystem and allow them to increase in numbers. Red borer (Zeuzera coffeae Niether) of order Lepidoptera reported to attacks the main stem of young teas in low country, Uva and Dickoya areas. Cockchafers species occur occasionally in tea nurseries and new clearings causing economic damage to tea plantations. The different species of Cockchafers, Holotrichia disparilis Arrow and Microtrichia costata Walker are very injurious to new clearings.

Isopteran were recorded from all the experimental sites and all of them represent a macropterous form of termites. Among the total lepidopteron catch $3.93 \%$ of tea tortrix from station 2 and $16.7 \%$ of Tea Tortrix from sta- 
tion 3 were captured throughout the year. Tea Tortrixs have outbreaks seasonally under certain agro-climatic in Sri Lanka and it is under perfect natural control in the low country tea plantations. Outbreaks occur in the upcountry from December to March/April and in the Uva region from June to August. Among the total Coleopterans 10, 4.5, 18.1, 11.7, 4.1 and $6 \%$ of Scarabidae beetles were reported from each experimental site and Cockchafers belong to the family Scarabaeidae. Among the Coleopterans, a negligible amount of Shothole borers were reported from station 2 only.

We recorded twelve species of bats belonging to six familiesby this study and eight species of them were insectivorous bats representing five different families. They include $R h i$ nolophus rouxii, Rhinolophus beddomei, Hipposideros speoris, Hipposideros lankadiva, Pipistrellus ceylonicus, Pipistrellus coromandra, Miniopterus fuliginosus and Megaderma spasma. The representation of bat families across the six study sites varied, with Rhinolophidae, represented at all stations. Family Hipposideridae, Megadermatidae, Vespertilionidae, and Miniopteridae all showed rather patchy distributions. In terms of mist net captures, $R$. rouxii was the most frequently recorded taxa. According to our results, station 1 had the highest species richness (with 5) whereas station 3 and station 5 (with only 2) had the lowest. The second highest species count was recorded from station 6. Station 2 and station 4 have similar species counts (3).

Horseshoe Bats of the genus Rhinolophus feed on a variety of insects, mainly Lepidoptera and Coleoptera (Stebbings 1977). Through this study, $R$. rouxii was recorded from all sites by feeding very close to the canopy of tea bushes and $R$. beddomei from stations $1 \&$ 6. Eckrich and Neuweiler (1988) reported that $R$. rouxii fed on a broad range of insects unselectively and scarabaeids beetles and termites were the more common in their diet. Live wood termites are reported as a key pest of tea in Sri Lanka. Cockchafer grubs of family Scarabaeidae performed economic damage to tea plants occasionally in local conditions and according to Eckrich and Neuweiler (1988), $R$. rouxii favoured scarabaeids beetles. The main dietary consumption of $R$. beddomei is Lepidoptera and Coleoptera and can forage comparatively large size insects than $R$. rouxii because it has a broader palate and it is reported that to prefer hard insects like beetles and also moths (Selva and Vanitharani 2014; Phillips 1980). Jones (1990) reported that $R$. ferrumequinum forages mainly of Lepidoptera and Coleoptera including cockchafer $M$. melolontha with a considerable number on Hymenoptera and Diptera. There is a big potential to use $R$. rouxii and R.beddomei as a successful biological control agent to integrated pest management programme in tea plantations.

Pavey et al. (2001) reported that Hipposideros speoris in Sri Lanka feed on Coleoptera, Lepidoptera, Diptera, Hemiptera, Isoptera, Hymenoptera and Neuroptera. H. speorisis reported to forage at twilight (Pavey et al. 2001). According to the study conducted in the dry zone of Sri Lanka by Pavey et al. (2001) reported that the $H$. speoris feed on a wide verity of pray including in Coleoptera, Lepidoptera, Diptera and also Hemiptera, Hymenoptera, Isoptera, Neuroptera with winged termites swarms at twilight. H. speoris was recorded to roost around three stations $(1,2 \& 6)$. Termite damage is a concern in this region and there is a prospect to use H. speoris to manage swarming termites in the sunset.

Great Leaf-nosed Bat (H. lankadiva), the largest of insectivorous bats in Sri Lanka was recorded from station 1 in a large rock cave sympatrically roosting with H.speoris and $R$. rouxii. Ecknch and Neuweiler (1988) reported that $H$. lankadiva mainly feeds on Scarabidae beetles selectively in Sri Lanka together with large slow-flying insects such as bugs or nuptial ants.

Kelaart'spistrelle Bats (P. ceylonicus) were 
recorded from station 2 and 3. Indian Pipistrelle Bat (Pipistrellus coromandra) was recorded only from stations 1 and 4 . Perveenand Rahman (2015) reported that the $P$. ceylonicus forage mainly on beetles, moths, flies and other insects and $P$. coromandra forage mainly on flies ants and other small insects.

Eastern Bent-winged Bat Miniopterus fuliginosus was only recorded in station 5. M. fuliginosus hunts mainly Lepidoptera and relatively large Coleoptera (Hu et al. 2011).

Lesser False Vampire Bat (Megaderma spas$m a)$ was observed at station 6 only. According to literature, M. spasma mainly feeds on big insects like grasshoppers and moths (Brosset 1962; Medway 1978), tettigoniid grasshoppers, Scarabaeidae beetles, cockroaches (Davison and Zubaid 1992), beetles, cicadas, Katydids and crickets (Balete 2010).

Tea is grown intensively as monoculture perennials but, most of the tea pests are seasonal. Many insects feed on tea plants and climatic change could poseto change plant-feeding insect to pest levels. Pest management strategies

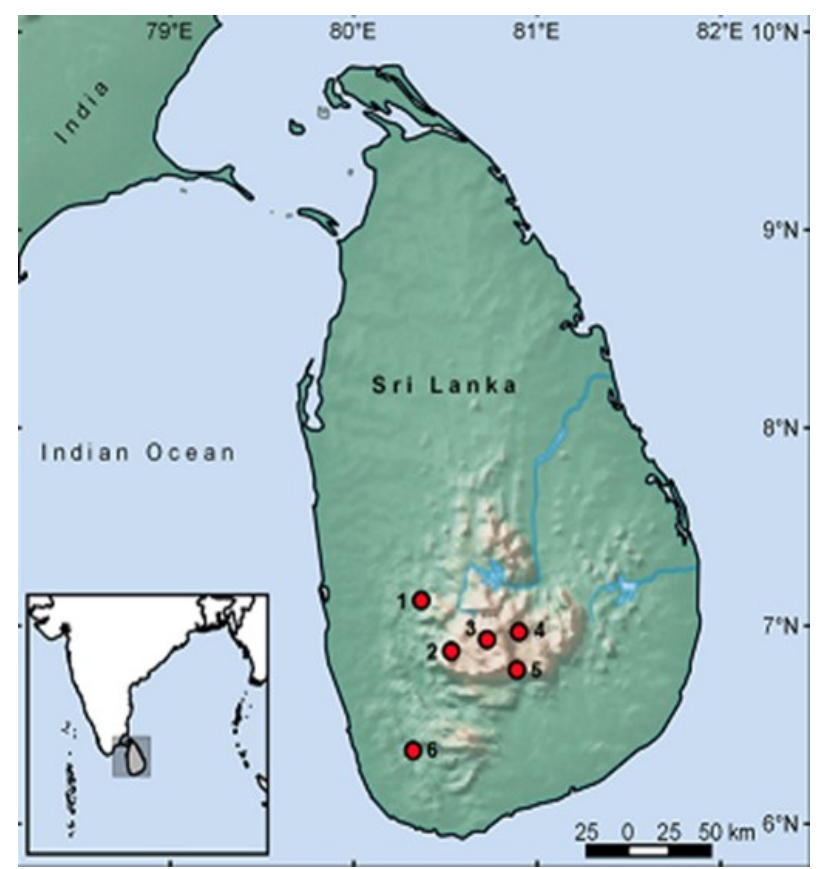

Figure 1: Location map of the study area based on biological pest control is significance to control insect pest in agroecosystems. Because tea ecosystems are open habitats, vertebrate diversity is comparatively less. Bats are good bioindicators to evaluate the biodiversity of a particular area (Jones et al. 2009). In addition, insectivorous bats could be used in the management of insect pest populations. Our study demonstrated that there is a considerable diversity of nocturnal insect as well as insectivorous bats in all selected tea plantations located in the different agroecological zone of Sri Lanka. The literature reviewed that insectivorous bats tend to be feed selectively or opportunistically with the availability of prey (Whitaker 1995; Whitaker et al. 1999). Therefore findings of this study emphasize that there is a huge potential to utilize insectivorous bates in tea pest management programme in Sri Lanka.

\section{CONCLUSION}

The abundance of nocturnal insects were high in tea plantations of Sri Lanka throughout the year. Insectivorous bat species were also recorded from all the study sites. Most of the tea pests are considered seasonal pests, it is a very good possibility to use generalist predators as effective biocontrol agents in tea pest control because generalist predators can be sustained

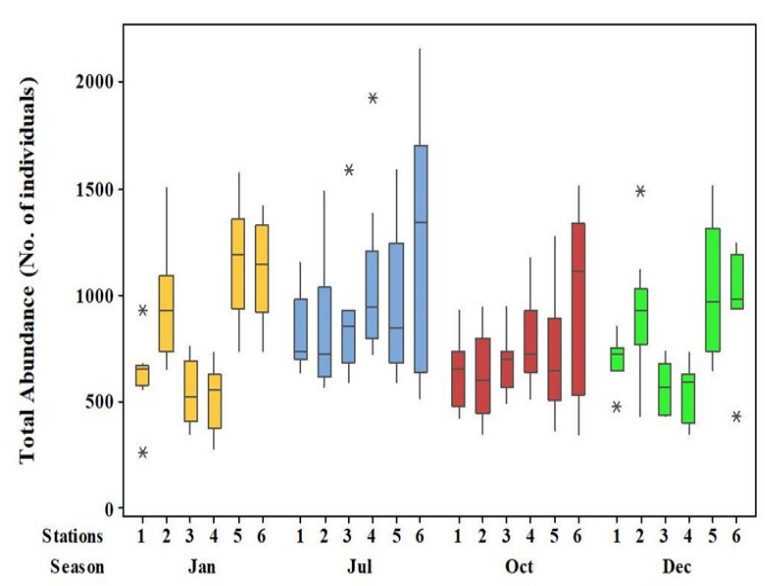

Figure 2: The mean $( \pm \mathrm{SD})$ insect richness for each sampling scale 
Table 4: Shannon's diversity indices $(\mathrm{H})$ of insects collected from each sampling site

\begin{tabular}{lllllll}
\hline Station & $\mathbf{1}$ & $\mathbf{2}$ & $\mathbf{3}$ & $\mathbf{4}$ & $\mathbf{5}$ & $\mathbf{6}$ \\
\hline January 2017 & $1.7066^{\mathrm{ab}}$ & $1.7280^{\mathrm{ab}}$ & $1.5660^{\mathrm{bc}}$ & $1.8430^{\mathrm{a}}$ & $1.7836^{\mathrm{a}}$ & $1.4630^{\mathrm{c}}$ \\
July 2017 & $1.2266^{\mathrm{c}}$ & $1.6556^{\mathrm{b}}$ & $1.7796^{\mathrm{a}, \mathrm{b}}$ & $1.8990^{\mathrm{a}}$ & $1.6430^{\mathrm{b}}$ & $1.7236^{\mathrm{b}}$ \\
October 2017 & $1.5203^{\mathrm{b}}$ & $1.6216^{\mathrm{b}}$ & $1.6196^{\mathrm{b}}$ & $1.8750^{\mathrm{a}}$ & $1.5573^{\mathrm{b}}$ & $1.6393^{\mathrm{b}}$ \\
December 2017 & $1.7140^{\mathrm{b}}$ & $1.6610^{\mathrm{b}}$ & $1.7746^{\mathrm{b}}$ & $1.9463^{\mathrm{a}}$ & $1.1636^{\mathrm{c}}$ & $1.7633^{\mathrm{b}}$ \\
\hline
\end{tabular}

Data are expressed as means $\pm \mathrm{SD}(\mathrm{n}=3)$. Values within a given row arenot followed by the same superscript letter are significantly different at $P \leq 0.05$ as determined by Duncan's Multiple Range Test.

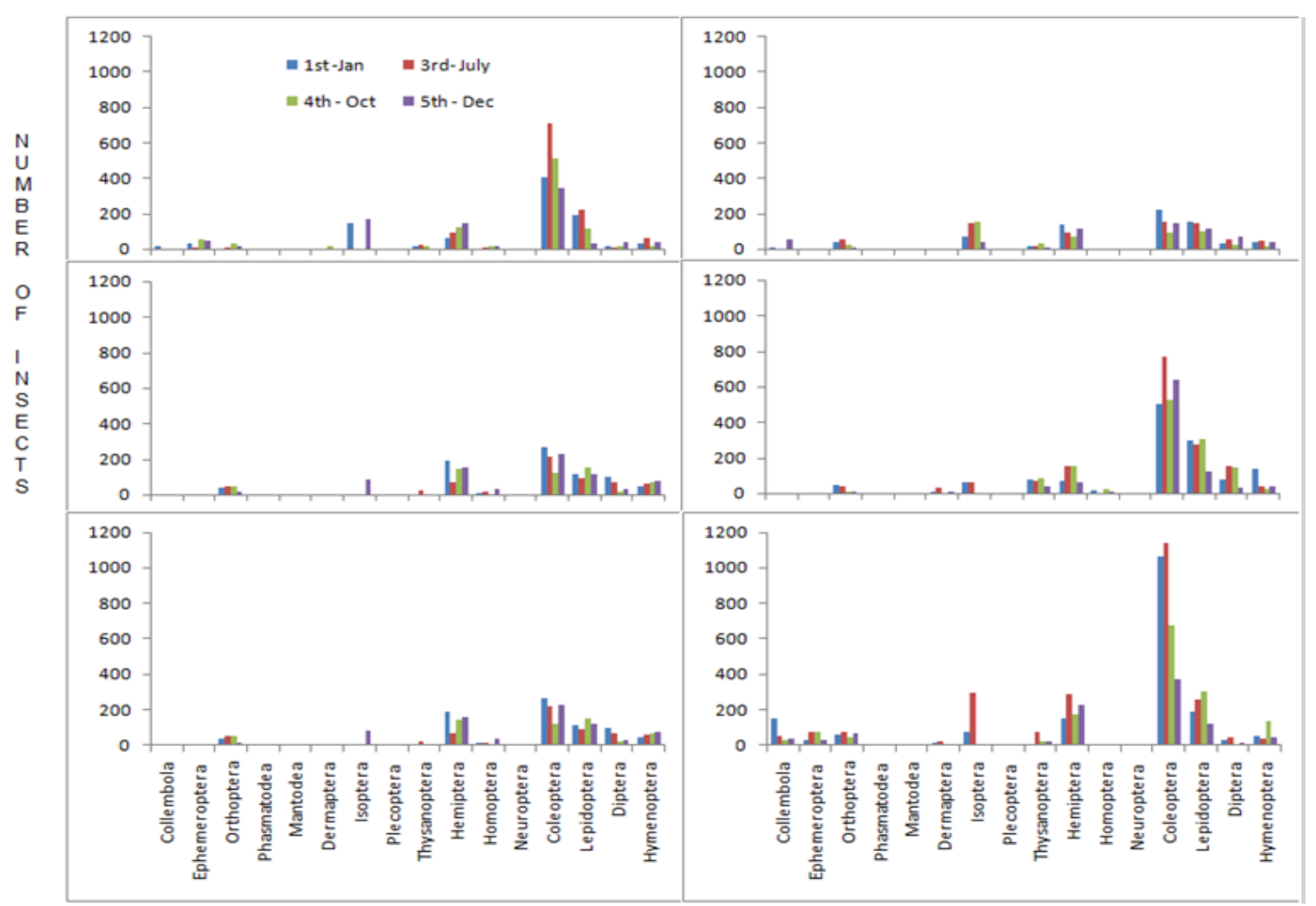

Figure 3: Total number of insects per insect order for each sampling scale

as opportunistic feeders throughout the year. Conservation of insectivorous bats as a generalist predator of insects in the tea agroecosystems in Sri Lanka as the potential to use as a biological pest control agent in the tea agroecosystems. Furthermore, when we compare with the earlier research link of the prey consumption of identified bat species, it is revealed that these bat species mostly prey on a broad range of insects including Lepidoptera, Coleoptera and Isoptera in which major pest of tea belong.
Further research is being conducted to understanding the prey preference of insectivorous bats by fecal pellet analysis. Introduction of the suitable bat boxes to increase the bat roosting site in tea land could help to conserve bats and approaches to enhance insectivorous bats activities in the tea lands should be considered in detail.

\section{ACKNOWLEDGMENT}

This work was supported by the National Research Council, Sri Lanka under Grant no 15111. We thank the Department of Wildlife 
Conservation, Sri Lanka for permission granted (permit no WL/3/19/17 and $\mathrm{WL} / 3 / 2 / 02 / 2016$ ) to carry out the research.

\section{REFERENCE}

Balete DS 2010 Food and roosting habits of the lesser false vampire bat, Megaderma spasma (Chiroptera: Megadermatidae), in a Philippine lowland forest. Asia Life Sciences, 4 (11):111129

Brosset A 1962 The Bats of Central and India, Part 11, Journal of Bombay Natural History Society. 59: 583-624.

Central Bank 2017 Annual Report. Central Bank of Sri Lanka, Colombo.

Cranham J 1966 Tea pests and their control. Annual Review of Entomology, 11 (1): 491-514.

Davison GWH and Zubuid A1992 Food habit of the Lesser false vampire bat, Megaderma spasma from Kuala Lompat, Peninsula Malaysia. Zeitschrifr fur Saugetierkunde 57:310-312.

Eckrich M and Neuweiler G1988 Food habits of the sympatric insectivorous bats Rhinolophus rouxi and Hipposideros lankadiva from Sri Lanka. Journal of Zoology, 215(4):729-737.

Hazarika LK, Bhuyan M and Hazarika BN 2009 Insect pests of tea and their management. Annual Review of Entomology, 54: 267-284.

Hu KL, WeiL, Zhu TT, Wang XZ, and Zhang LB 2011 Dietary composition, echolocation pulses and morphological measurements of the long-fingered bat Miniopterus fuliginosus (Chiroptera: Vespertilionidae). Zoological Research, 32(2):163-167

Jones G, Jacobs DS, Kunz TH, Willig MR and Racey PA 2009 'Carpe noctem: the importance of bats as bioindicators', Endangered Species Research, 8:93-115.

Jones G 1990 Prey selection by the greater horseshoe bat (Rhinolophus ferrumequinum): optimal foraging by echolocation. The Journal of Animal Ecology, 59:587-602

Magurran AE 1988 Ecological diversity and its measurement: Princeton university press. Princeton, New Jersey

Medway L 1978 The wild mammals of Malay (Peninsula Malaysia) and Singapore. Oxford University Press.Malaysia, 128p

Morris EK, Caruso T, Buscot F, Fischer M, Hancock C, Maier TS, Meiners T, Müller C, Obermaier E, Prati D, Socher SA, Sonnemann I, Wäschke N, Wubet T, Wurst S and Rillig MC 2014 Choosing and using diversity indices: insights for ecological applications from the German Biodiversity Exploratories. Ecology and Evolution, 4: 3514-3524.

Pavey CR, Burwell CJ, Grunwald JE, Marshall CJ and Neuweiler G 2001 Dietary Benefits of Twilight Foraging by the Insectivorous Bat Hipposideros speoris. Biotropica, 33(4):670-681.

Perveen F and Rahman Faiz-ur 2015 Characteristics of the First Record of Bat (Mammalia: Chiroptera) Fauna from Peshawar and Adjacent Areas, Khyber Pakhtunkhwa, Pakistan. Global Journal of Animal Scientific Research. 3(1):148-160.

Phillips WWA 1980 Manual of the mammals of Sri Lanka, part I Second Revised Edition Wildlife and Nature Protection Society of Sri Lanka, Colombo, Sri Lanka: 267

SAS Institute, 1996. SAS/STAT User guide for personal computers, version 9.1 ed., SAS Institute, Cary, NC

Shannon CE 1948 A mathematical theory of communication. Bell System Technical Journal, 27:379-423.

Selva PS and Vanitharani J 2014 Insect pest management by the horseshoe bats (Rhinolophus species) in the forest ecosystem of Kalakad Mundanthurai Tiger Reserve, India. Scrutiny Inter- 
national Research Journal of Biological and Environmental Sciences, 1 (5):15-32

Stebbings RE 1977 Order Chiroptera-Bats. In: Corbet, Southern (eds) The handbook of British mammals. Blackwell Publ, Oxford.

Vitharana SI 2003 ' 75 Years Research in Tea entomology, Acarology and Nematology'. In: Modder, W. W. D. (ed.), Twentieth Century Tea Research in Sri Lanka, Tea Research Institute of Sri Lanka, Talawakelle, Sri Lanka.

Walgama Rand Pallemulla R2 005 The distribution of shot-hole borer, xyleborus fornicatus Eichh. (Coleoptera: Scolytidae), across tea-growing areas in Sri Lanka. a reassessment, Sri Lanka Journal of Tea Science, 70 (2): 105120.

Whitaker Jr JO 1995 Food availability and opportunistic versus selective feeding in insectivorous bats. Bat Research News, 35:75-77.
Whitaker Jr JO, IssacSS, Marimuthu G, and Kunz TH 1999 Seasonal variation in the diet of the Indian pygmy bat, Pipistrellus mimus, in southern India. Journal of Mammalogy, 80(1): 60-70.

Wickramasinghe LP, Harris S, Jones G and Jennings NV 2004 Abundance and species richness of nocturnal insects on organic and conventional farms: effects of agricultural intensification on bat foraging. Conservation Biology, 18: 1283-1292.

Wickramasinghe LP, Harris S, Jones G and Vaughan N 2003 Bat activity and species richness on organic and conventional farms: impact of agricultural intensification. Journal of Applied Ecology, 40:984-993.

Wijesekara A and Wijesinghe DP 2003 History of insect collection and review of insect diversity in Sri Lanka.Ceylon Journal of Science (Biological Science), 31:.43-59. 